see Day \& Schleicher, 2006). But these findings have stirred controversy. One skeptic criticized emergent leadership research as lacking external validity, and pointedly predicted that in real-world contexts the attempted leadership behaviors of high self-monitors would be perceived as "both duplicitous and reprehensible" (Bedeian $\&$ Day, 2004, pp. 707-708). From this skeptical perspective, the emergence of high self-monitors as leaders represents ephemeral impression management in the context of laboratory experiments.

This skepticism toward high self-monitoring leadership includes a rejection of the possibility that high self-monitors might build trust among their colleagues. The chameleon-like high self-monitors with their changeable attitudes and behaviors are said to lack the "right stuff" to be seen as leaders. The impression management skills characteristic of high self-monitors (involving ingratiation and selfpromotion-Turnley \& Bolino, 2001) are seen by some leadership experts as likely to undermine the trust of colleagues in real organizations by exemplifying inauthentic leadership (Cooper, Scandura, \& Schriesheim, 2005). We address this unresolved controversy concerning high and low self-monitors through an examination of whether and how self-monitoring relates to leadership in organizational contexts.

There are three contributions related to leadership emergence. First is the contribution to leadership research. We show that flexibility (in terms of a high selfmonitoring orientation) is associated with brokering trust relations to win attributions of leadership. Second is the contribution to brokerage theory and research. We provide an answer to the puzzle (raised by Burt, 1992) of why some people more than others benefit from the occupation of a brokerage position in the trust network. Third is the contribution to self-monitoring theory and research. We show that the emergence of high self-monitors as leaders is associated with the provision of advice concerning work-related matters to colleagues rather than being merely impression management.

Our research ties in with the long-standing debate concerning the micro-origins of social-structural outcomes. We know that the natural proclivity of individuals is to cluster together in similar groups creating cohesion locally but the possibility of fragmentation at the level of the overall organization (Granovetter, 1973). This paradox of local cohesion within overall fragmentation is a situation that demands informal leadership to connect across clusters (Burt, 1992). The important question arises as to who is likely to exemplify leadership in connecting across social divides. We seek to provide insight into this question in this paper.

\section{Self-Monitoring and Leadership}

Self-monitoring theory suggests that high self-monitors, relative to lows, are likely to emerge as leaders in work situations not just in terms of promotions (Kilduff \& Day, 1994), but also in terms of informal leadership perceptions. High self-monitors, acutely attentive to social cues, take an active, initiatory posture in social interaction whereas low self-monitors generally adopt a non-directive approach. For example, 
when two unacquainted people of the same sex find themselves in a waiting room together, those individuals who are higher in self-monitoring tend to speak first and to initiate more frequent conversations (Ickes \& Barnes, 1977). The high selfmonitors tend to "take the pulse of their social surroundings" (Snyder, 1987, p. 33) in tailoring self-expressions to the role demands appropriate to different welldefined situations. In contrast, low self-monitors tend to "march to the beat of their own inner drummer" (p. 33) in seeking opportunities to be themselves irrespective of the situation. For example, one study showed that those higher in self-monitoring (relative to those lower in self-monitoring) tended to base their estimates of when they should intervene to help a colleague suffering an epileptic fit on information concerning what others had done in a similar situation (Kulik \& Taylor, 1981). Further, managers higher in self-monitoring relative to managers lower in selfmonitoring tend to be active in the provision of help to those suffering emotional problems in the workplace (Toegel, Anand, \& Kilduff, 2007). Overall, high selfmonitoring employees (relative to low self-monitoring employees) tend to be actively engaged in more workplace projects (as measured by the number of formal work relationships they develop) (Mehra, Kilduff, \& Brass, 2001). Thus, high selfmonitors are likely to be perceived as leaders in organizations in part because of their interest in the attitudes and behaviors of others, whereas low self-monitors are less likely to be perceived as leaders because of their consistent focus on themselves. High self-monitors, relative to lows, develop an active repertoire of role enactments related to leadership, including motivating others by setting clear goals, showing that efforts will be rewarded, encouraging others to cooperate, being supportive, and listening to others' suggestions (Snyder, 1987, p. 89). The overall picture, then, suggests that high self-monitors, relative to lows, are more likely to be seen to be involved in informal leadership roles given their focus on engagement with and management of coworkers.

Hypothesis 1: High self-monitors, relative to low self-monitors, are more likely to be perceived as leaders by organizational members.

We want to go beyond this overall prediction to expand our understanding of how self-monitoring relates to informal leadership. A credible argument has been made (Bedeian \& Day, 2004) concerning why people in organizations might scorn the leadership of those who appear to flexibly change their opinions. Such inconsistency, it has been argued, is incompatible with being perceived to be a leader. Our understanding of self-monitoring theory leads us to a quite different predictionthat high self-monitors, relative to lows, are likely to be central in terms of providing advice to coworkers.

Giving Advice About Work-Related Matters Within work organizations the provision of advice is a key aspect of the leadership role (Carter, Haythorn, Shriver, \& Lanzetta, 1951; Sorrentino \& Field, 1986; see the brief review in Neubert \& Taggar, 2004, p. 180). People central in advice networks tend to be those who are also recognized as leaders by their colleagues (Bono \& Anderson, 2005). And there are 
several prior studies suggesting the likelihood that self-monitoring orientation relates to involvement in the provision of workplace advice to colleagues.

For example, we know that high self-monitors, relative to lows, are better at scanning the social world for information concerning others, and are also better at remembering such information (Berscheid, Graziano, Monson, \& Dermer, 1976). If valuable information is available in the organization relevant to workplace problems, then it is the high self-monitors who are likely to collect and utilize such information. High self-monitors tend to be more successful than low self-monitors at eyewitness identification (e.g., Hosch, Leippe, Marchioni, \& Cooper, 1984) and at detecting people's intentions (Jones \& Baumeister, 1976). Thus, in work situations, high self-monitors are more likely than the lows to grasp what problems people are trying to solve. Further, high self-monitors strive to establish reputations as generous exchange partners - people who are willing to provide help to others without expecting to be helped in turn (Flynn, Reagans, Amanatullah, \& Ames, 2006). Overall, then, high self-monitors are likely to emerge as central in advice giving networks in organizations because they collect important knowledge from the social environment and recognize when such knowledge is likely to be of use in helping others.

Hypothesis 2: High self-monitors, relative to low self-monitors, are more likely to be sought for advice by organizational members.

Finally, we come to the thorny issue of trust. Surely, it must be, as Bedeian has argued (Bedeian \& Day, 2004), that the true-to-themselves low self-monitors, consistent in their attitudes across different situations, are more likely to be trusted than the chameleon-like highs? Does not the changeability of the high self-monitoring orientation undermine trust? Self-monitoring theory suggests a more complex picture. Yes, low self-monitors, because of the consistency they demonstrate between their attitudes and behaviors (Zanna, Olson, \& Fazio, 1980), can build reputations as principled and autonomous individuals. But, high self-monitors are also likely to exhibit autonomy and independence when normative climates favor such nonconformity (Snyder \& Monson, 1975).

Perhaps surprisingly, given the flexibility that high self-monitors exhibit, there is no general association between self-monitoring and conformity to social pressure (Santee \& Maslach, 1982; Snyder, 1987, p. 37). Where high self-monitors do exhibit consistency is in presenting a general appearance of friendliness and the absence of anxiety (Lippa, 1978), and this general appearance is likely, one could argue, to engender trust. Thus, on the basis of self-monitoring-theory, it is difficult to formulate any simple relationship between self-monitoring and the extent to which individuals are trusted by others, given that both the principled low self-monitoring orientation and the sociable high self-monitoring orientation offer bases for establishing trust. It is possible, however, to respond to the request from the leading exponent of structural hole theory to "take the next analytical step" (Burt, 1992, p. 275) in understanding why some individuals rather than others benefit from brokerage opportunities in the trust network. 
Trust Brokerage From a self-monitoring perspective, there is likely to be a difference in how the low and high self-monitors use their positions in the trust network. All individuals who "broker" between unconnected others occupy positions of autonomy (Merton, 1968; Simmel, 1955) that confer advantages in negotiations (Markovsky, Willer, \& Patton, 1988) and in access to diverse knowledge and other resources (Burt, 1992). Such brokers are likely to be seen as leaders (Bavelas, 1950; for a review, see Shaw, 1964). However, the extent to which individuals who broker between disconnected others are able to take advantage of the brokerage position to emerge as leaders in the eyes of others is likely to vary. In the specific case of brokerage in the trust network, the broker connects two other people who do not trust each other, and this situation calls for particular skills in managing relationships. The broker in such a situation is in danger of being regarded by each of the nontrusting parties as partial to the other (Podolny \& Baron, 1997, p. 676). High selfmonitors, relative to low self-monitors, are more skilled at overcoming such negative impressions (Flynn, Chatman, \& Spataro, 2001). Indeed, high self-monitors, relative to low self-monitors, are more skilled at social interactions (Furnham \& Capon, 1983 ) in terms of being active in conversations (Ickes \& Barnes, 1977), pacing conversations (Dabbs, Evans Hopper, \& Purvis, 1980), using humor (Turner, 1980), and using a range of other techniques to ensure successful interactions (Snyder, 1987, p. 42).

We suggest, therefore, that the relationship between trust brokerage and leadership emergence is likely to be stronger for high self-monitors than for low selfmonitors. Relative to low self-monitors, high self-monitors are particularly motivated to construct and project images with the intent of impressing others. Given this "status enhancement motive" (Gangestad \& Snyder, 2000) and evidence that high self-monitors are able to act out different, and potentially incompatible, roles with different groups of people (Snyder, 1987, pp. 62-63), we suggest that high self-monitors will be particularly likely to leverage positions of brokerage in the trust network to facilitate the work of others, thus elevating their reputations as emergent leaders.

Hypothesis 3: The relationship between trust brokerage and leadership emergence will be stronger for high self-monitors than for low self-monitors.

\section{Methods}

Site We collected data from a high-technology company located in the northeastern United States. The company researched, produced, and marketed high-precision chromatographic equipment that it sold to analytical laboratories and other clients interested in testing the composition of a wide array of products, such as foods, fragrances, environmental pollutants, pharmaceuticals, and petrochemicals. The self-styled "head-coach" founded the company when he quit his job at a rival firm to take advantage of a business incubator program at a nearby university. Twelve 
years later, when this study was conducted, the company had grown from 1 to 116 employees. The firm used a relatively flat organizational structure (only three formal hierarchical levels) to help it compete in a fast-paced industry dominated by large, well-funded rivals, such as Hewlett-Packard. Of the 116 employees, 95 were in non-supervisory positions. The company was housed in a building purposefully designed to promote informal interactions among all employees. At the heart of the building was a large sunlit atrium, complete with large tropical plants, a waterfall, and a campus-style cafeteria. The firm had won prestigious awards for its entrepreneurial culture, environmentally friendly products, and success in recruiting, training, and promoting women.

Data We collected data on leadership perceptions, self-monitoring, and the trust network using a questionnaire sent to all 116 employees (68 men and 48 women). 102 people responded to the questionnaire, an overall response rate of $88 \%$. Missing data reduced the sample size to 91 . Respondents were not significantly different from non-respondents with regard to tenure or sex.

\section{Measures}

Trust Network To learn about the network of interpersonal trust relations we used the roster method: we asked respondents to look at a list of employees' names and place a check next to the names of "... those [people] whom you especially trust." We defined trusted individuals as "people with whom you would feel comfortable sharing personal or otherwise confidential information; people who you feel confident would not use the information to take advantage of you." The definition of trust was based on Rousseau, Sitkin, Burt and Camerer (1998), who examined how trust has been conceptualized and measured across a range of social science disciplines. Their review concluded that trust is "a psychological state comprising the intention to accept vulnerability based upon positive expectations of the intentions or behavior of another" (p. 395). This is also the definition used by Dirks and Ferrin (2002, p. 612) in their meta-analytic study of trust in leadership; and it is consistent with the approach to measuring the trust network adopted by Sparrowe and Liden (2005, p. 517). The sociometric data on trust relations were arranged in a $102 \times 102$ matrix containing 10,302 observations on all possible pairs of people.

Advice Network We also used the roster method to learn about advice relations. We asked employees to look down a list of names of all employees and place a check next to the names of “... the people from whom you seek advice about workrelated matters. These are the people you turn to when you have a work-related problem or when you need advice about a work-related decision you have to make." This definition of advice relations is based on earlier network studies of advice relations in the workplace (e.g., Ibarra, 1992; Sparrowe \& Liden, 2005). The sociometric data on advice relations were arranged in a $102 \times 102$ matrix containing advice relations among all possible pairs of people. 


\section{Independent Variables}

Trust Brokerage To assess the extent to which an individual occupied a brokerage position in the trust network, we used the social network software UCINET VI (Borgatti, Everett, \& Freeman, 2002) to calculate Burt's measure of "network constraint" (for the mathematical formula and an extended discussion of the measure, see Burt, 1992, pp. 50-81; Borgatti, Jones, \& Everett, 1998). Network constraint can range from 0 to 1 . A summary index, constraint "measures the lack of brokerage opportunities" (Burt, 2007, p. 125) within a network. The more that a person's contacts are directly tied to one another, the higher is the constraint on the individual. This measure has been widely used to assess structural brokerage in prior studies (e.g., Burt, 1997; Seibert, Kraimer, \& Liden, 2001). We reversed the sign of the measure so that the index can be directly interpreted as representing the presence of brokerage opportunities (rather than the absence of brokerage opportunities).

Self-Monitoring We used the revised 18-item, true-false version of the selfmonitoring scale to code self-monitoring orientation (Snyder \& Gangestad, 1986). Scale items included "I would probably make a good actor," and "I would not change my opinions (or the way I do things) in order to please someone or win their favor" (reverse coded). The 18-item scale has higher internal consistency than the original 25-item measure. Cronbach's alpha for the scale in this study was .80 . Research suggests that self-monitoring is a stable aspect of personality through the lifespan (Gangestad \& Snyder, 1985; Jenkins, 1993, p. 84). A meta-analytic review of the literature on self-monitoring in the workplace concluded that this scale has sound psychometric properties, as evidenced by high levels of internal consistency, reliability, and predictive validity (Day, Schleicher, Unckless, \& Hiller, 2002).

\section{Dependent Variables}

Leadership Perceptions The construct of leadership has been conceptualized and measured in a number of different ways in the organizational literature (see R. Hogan, Curphy, \& Hogan, 1994). Nonetheless, a longstanding distinction relevant to our investigation is between leadership effectiveness and leadership emergence (Lord, De Vader, \& Alliger, 1986). Whereas leadership effectiveness is conceptualized in terms of group and organizational performance, leadership emergence "is based on the extent to which an individual is viewed as a leader by others and is, therefore, inherently tied to others' perceptions" (Day \& Schleicher, 2006, p. 693).

We assessed the extent to which respondents perceived others to be leaders by counting the number of times each individual was nominated as a leader. Specifically, we asked each respondent to look down a list of names of employees and place a check next to the name of the individuals whom they perceived to be leaders. We explained on the questionnaire that individuals perceived as leaders "may or may 
not be officially designated as leaders by...management." We did not specify what we meant by the term "leader" because we were interested in capturing respondents' implicit theories of leadership (Lord \& Maher, 1991/1993, p. 11).

Advice Centrality We assessed centrality in the advice network by counting the number of times an individual was identified by others as someone they tended to turn to for advice on work related matters.

\section{Control Variables}

Rank This variable was coded as 1 for supervisors and as 0 for non-supervisors. The data for coding this variable came directly from company records. We controlled for rank because high-ranking individuals, due to the resources they control and the prestige they enjoy, are likely to garner informal leadership influence on the basis of their reward power (French \& Raven, 1959).

Tenure Taken from company records, this was the number of months the person had been employed by the company.

Job Performance In the research on work organizations, the majority of performance ratings tend to come from supervisors (Bretz, Milkovich, \& Read, 1992, p. 331). Meta-analytic evidence suggests that supervisory evaluations represent valid assessments of true performance (Arvey \& Murphy, 1998, p. 163). Our threeitem measure of job performance was based on confidential ratings provided by each individual's direct supervisor. Performance ratings that are collected for research purposes tend to more reliable and valid than those obtained for administrative purposes (Wherry \& Bartlett, 1982). The three items that made up our measure were selected on the basis of multiple discussions with a panel comprising the firm's human resources director, a long tenured member with broad knowledge of the company, and four employees who represented a range of different job types at the firm. The items asked supervisors to rate subordinates in terms of (a) their "overall job performance" ( $1=$ poor, $5=$ excellent $)$; (b) the likelihood that the subordinate would "achieve future career related success (such as promotions, awards, bonuses, and involvement in high profile projects)" at the company; and (c) would be someone the supervisor would pick as a successor for their job $(1=$ highly unlikely; $5=$ highly likely). The reliability of the scale as measured by Cronbach's alpha was .83

We considered and then rejected the inclusion of individual sex (male/female) as a control variable. This variable was insignificant in all the analyses reported below, but its inclusion produced poorer fitting models. 


\section{Analyses}

The dependent variables in our analyses - the number of leadership nominations received by an individual, and the number of times an individual was cited as someone others turned to for work related advice - are count variables. For these kinds of data, Poisson-based regression models are more appropriate than Ordinary Least Squares (OLS) regression. However, our data showed clear evidence of overdispersion (e.g., after fitting the ordinary Poisson regression model, the Pearson chi-square goodness-of-fit statistic divided by degrees of freedom was much larger than 1). Therefore, we used the negative binomial variant of Poisson regression that explicitly includes a parameter for over-dispersion (see Hilbe, 2008). In negative binomial regression, the $\log$ of the expected values $(\mu)$ is a linear function of the independent variables plus the dispersion parameter:

$$
\log (\mu)=\text { intercept }+\mathrm{b} 1 * \mathrm{X} 1+\mathrm{b} 2 * \mathrm{X} 2+\ldots .+\mathrm{b} 3 * \mathrm{Xm}+\varepsilon \text {. }
$$

We employed the Likelihood Ratio (LR) test to assess the comparative goodness of fit between models (Huelsenbeck \& Rannala, 1997). The LR test compares the likelihood scores of two models. The LR statistic, which follows a chi-square distribution, assesses whether the addition of an additional parameter (e.g., selfmonitoring) leads to a significantly better fitting model than a baseline model (e.g., a model containing just the control variables). To test the interaction Hypothesis 3 , we mean-centered measures of self-monitoring and trust brokerage and multiplied them to create a single interaction term. We then included this interaction term in the regression equation containing control variables, self-monitoring, and trust brokerage.

\section{Results}

The descriptive statistics in Table 11.1 show that the typical non-supervisory employee had worked for the firm for four-and-a-half years, was seen as a leader by nine other people, was turned to for advice by 16 other people, and was regarded by the supervisor as a high performer $(M=10.15$ on a 15 -point scale). Compatible with the first two hypotheses, individuals high in self-monitoring, compared with those low in self-monitoring, tended to receive more leadership nominations $(r=.23$, $p<.05)$ and more nominations as advice providers $(r=.25, p<.05)$. Further, selfmonitoring was related to the tendency to occupy a role as a broker trusted by those who did not trust each other $(r=20, p<.10)$. Tables 11.2 and 11.3 show the results of tests of hypotheses. All of the binomial regression models in these tables demonstrate goodness-of-fit ratios close to one (the chi-square statistic divided by the degrees of freedom) indicating well-fitting models. 
Table 11.1 Means, standard deviations, and correlations of the variables

\begin{tabular}{lrrrrrrrr}
\hline Variable & $M$ & \multicolumn{1}{c}{$S D$} & 1 & 2 & 3 & 4 & 5 & 6 \\
\hline 1. Rank & 0.22 & 0.42 & & & & & & \\
2. Tenure & 53.95 & 39.25 & .19 & & & & & \\
3. Job performance & 10.15 & 2.75 & $.25^{*}$ & $.28^{* *}$ & & & & \\
4. Self-monitoring & 0.07 & 0.08 & $.18^{+}$ & & & & & \\
5. Trust brokerage & $0.29 * *$ & 0.14 & .08 & $.20^{+}$ & & & & \\
6. Perceived & $0.72^{* * *}$ & 0.29 & $.23^{*}$ & $.25^{* *}$ & $.35^{* * *}$ & $.23^{*}$ & $.36^{* *}$ & \\
leadership & & & & & & & & \\
7. Advice centrality & 15.87 & 11.11 & $.60^{* * *}$ & $.28^{* *}$ & $.23^{*}$ & $.25^{*}$ & $.52^{* * *}$ & $.74^{* * *}$ \\
\hline
\end{tabular}

Note ${ }^{+} p<.10 ; * p<.05 ; * * p<.01 ; * * * p<.001$

Model 1 in Table 11.2 shows that each of the three control variables (individual's rank, tenure in the organization, and job performance) significantly predicted the extent to which the individual was perceived as a leader. Recall that the first hypothesis suggested that the higher the self-monitoring score, the more the individual would be perceived as a leader. We found support for this prediction in the regression analysis summarized in Model 2, which shows that the addition of selfmonitoring significantly improved model fit over the controls-only Model 1 $(\chi=7.86, p<.01)$.

Thus, high self-monitors tend to be perceived as leaders. But are they also perceived as advice providers as suggested by Hypothesis 2? The answer is yes, as shown by the analyses summarized in Table 11.3. Controlling for the individual's rank, tenure, and job performance, the addition of self-monitoring in Model 2 significantly improved model fit over the base-line Model $1(\chi=4.80, p<.05)$. More co-workers report that high self-monitors, relative to low self-monitors, provide them with advice.

Hypothesis 3 suggested that the self-monitoring scores of those individuals who were trusted by people who distrusted each other would predict emergent leadership. We found support for this trust-leveraging hypothesis. As shown in Table 11.2, Model 5, the interaction between self-monitoring and trust brokerage was significant $(p<.01)$. The inclusion of the interaction term improved model fit relative to the main-effects Model $4(\chi=5.32, p<.05)$, suggesting that high self-monitors, relative to low self-monitors, leveraged go-between positions in the trust network to emerge as leaders in the eyes of others.

To more closely examine the form of these interactions, we constructed a split plot following the procedures described in Aiken and West (1991). The form of the plot depicted in Fig. 11.1 shows support for Hypothesis 3: although trust brokerage was positively related to the number of leadership nominations received for both high self-monitors and low self-monitors, this relationship was significantly stronger for highs than for lows. 


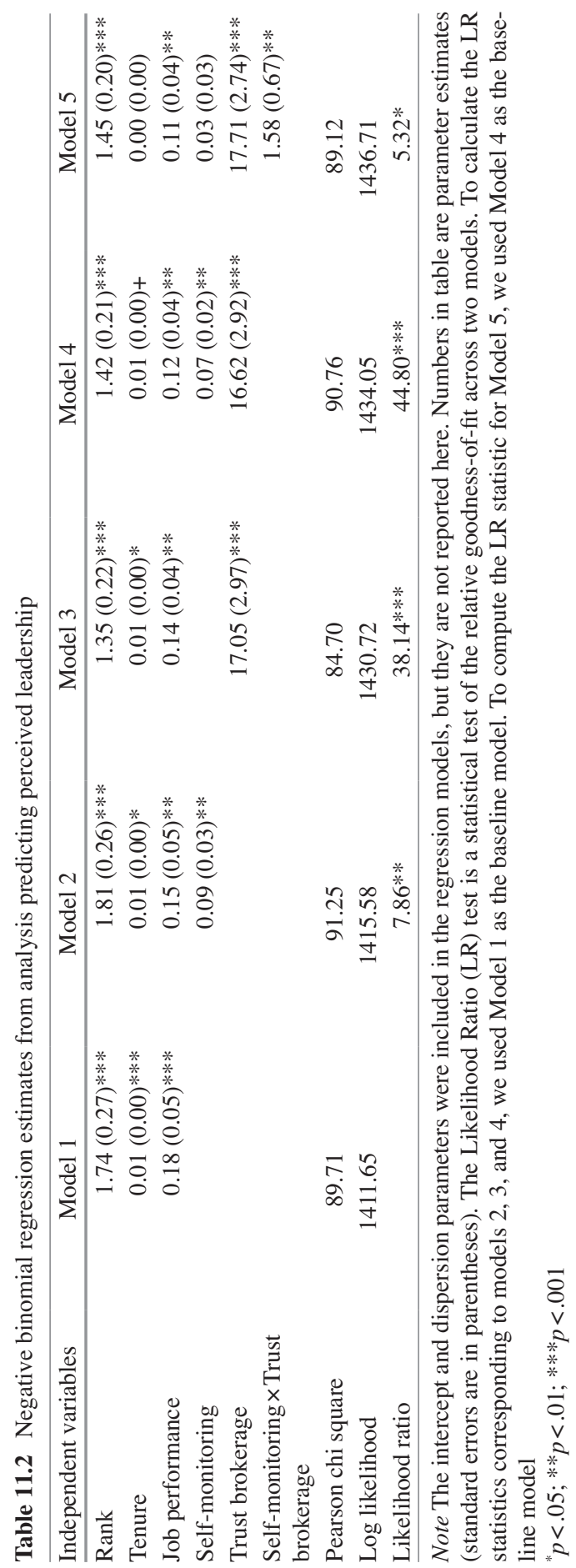


Table 11.3 Negative binomial regression estimates from analysis predicting advice centrality

\begin{tabular}{lcc}
\hline Independent variables & Model 1 & Model 2 \\
\hline Rank & $.68(0.17)^{* * *}$ & $0.70(0.16)^{* * *}$ \\
Tenure & $0.01(0.00)^{*}$ & $0.01(0.00)^{*}$ \\
Job performance & $0.04(0.03)$ & $0.03(0.03)$ \\
Self-monitoring & & $0.04(0.02)^{*}$ \\
Trust brokerage & & \\
Self-monitoring x trust brokerage & 86.75 & 86.87 \\
Pearson chi square & 2870.65 & 2873.25 \\
Log likelihood & & $4.80^{*}$ \\
Likelihood ratio & & \\
\hline
\end{tabular}

Note The intercept and dispersion parameters were included in the regression models, but they are not reported here. Numbers in table are parameter estimates (standard errors are in parentheses). The Likelihood Ratio (LR) test is a statistical test of the relative goodness-of-fit across two models. To calculate the LR statistic for model 2 we used Model 1 as the baseline model ${ }^{*} p<.05 ; * * p<.01 ; * * * p<.001$

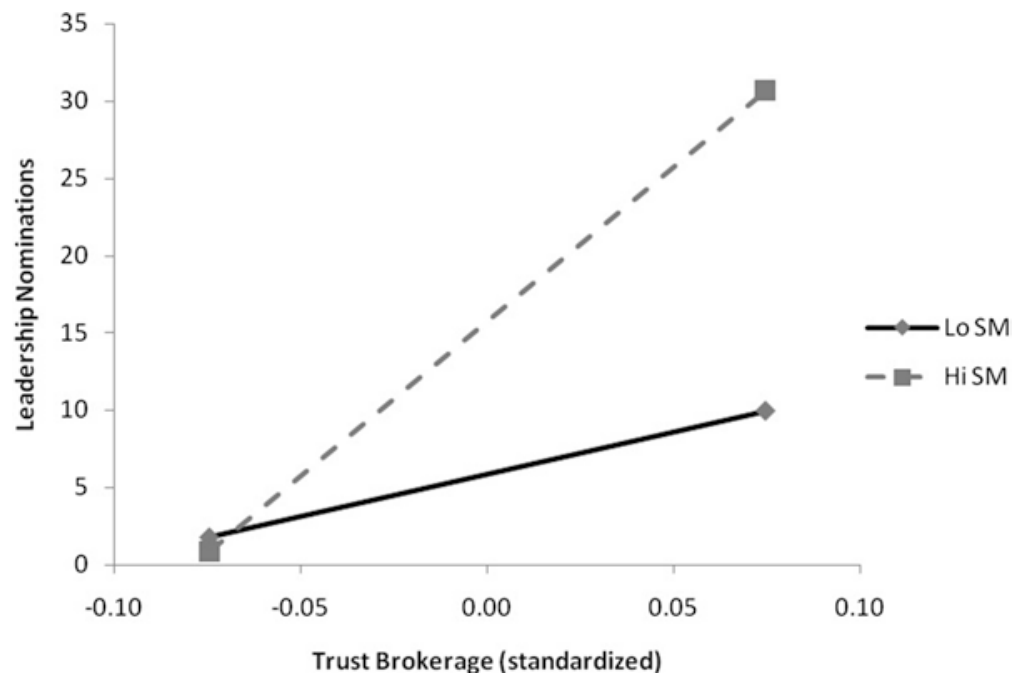

Fig. 11.1 Plot of the relationship between trust brokerage and number of leadership nominations received for high and low self-monitors (Design by authors) 


\section{Discussion}

Are high self-monitors likely to emerge in actual workplace settings as leaders in the eyes of others? Critics have pointed out that "subjects in laboratory studies... rarely feel accountable to others for the positions they take" (Tetlock, 1992, p. 335) and evidence suggests that laboratory studies may have inflated the relationship between self-monitoring and leadership emergence (Day et al., 2002, p. 394). Our results showed that self-monitoring was significantly related to leadership emergence in the workplace. Further, the leadership emergence of high self-monitors was facilitated by earning the trust of those who did not trust each other. Relative to low self-monitors, the high self-monitors were also active in the provision to colleagues of workplace advice. From these results, we build a picture of the high selfmonitoring emergent leader as someone who notices problems and ameliorates them through the provision of advice. The high self-monitoring style of leadership is not, as some have suggested, an epiphenomenon of laboratory experiments, but is recognized by workplace colleagues.

Particularly interesting is the possibility that the chameleon-like style of the high self-monitor helps rather than hurts leadership emergence. High self-monitors are likely to segregate their audiences from each other, acting out different and even incompatible roles across social settings (Snyder \& Gangestad, 1982; Snyder, Gangestad, \& Simpson, 1983). Although critics might characterize such role flexibility as detracting from leadership, the alternative possibility, suggested by our results, is that the high self-monitoring, purposively sociable orientation (Ickes \& Barnes, 1977) toward quite different social settings can help high self-monitors play a vital role in brokering across social divides. Indeed, high self-monitors (compared to low self-monitors) show leadership in resolving social dilemmas by contributing to the general welfare of others (De Cremer, Snyder, \& Dewitte, 2001).

\section{Contribution to Theory and Research}

Whereas prior work has speculated that high self-monitors may be perceived by others to lack leadership integrity because of the variability in their behaviors (Simons, 2002), our work has emphasized that high self-monitoring flexibility may enhance perceptions of leadership by facilitating coordination across social divides. Critics have tended to perceive the high self-monitoring style of leadership as lacking authenticity (Ilies, Morgeson, \& Nahrgang, 2005) but research has failed to support this proposition (Tate, 2008). Our results show that high self-monitors tend to provide advice to more people than do low self-monitors, and that high selfmonitors appear to be particularly well suited to playing the role of broker between parties that do not trust each other. The flexibility of high self-monitors, therefore, expresses itself in terms of centrality in advice networks and the ability to effectively broker trust relations to win attributions of leadership. 
The current study contributes to brokerage theory and research (e.g., Burt, 2005) an emphasis on the ways in which different kinds of people can take differential advantage of brokerage positions. Being trusted by people who do not trust each other has been theorized in prior work to provide both the opportunity and the motivation for brokerage (Burt, 1992, pp. 34-35). However, we show that, with respect to being recognized by their peers as leaders, high self-monitors, relative to low self-monitors, are more likely to benefit from the occupation of a structurally advantageous network position. The occupation of a structurally advantageous position, therefore, may well be more advantageous for some (i.e., high self-monitors) relative to others (i.e., low self-monitors). The incorporation of theoretically relevant personality differences can enhance the predictive and explanatory power of network theory.

The paper addresses the controversy in the self-monitoring literature concerning the kind of leadership that high self-monitors are likely to bring to real organizations. From our research, we show that high self-monitors, relative to low selfmonitors, are more central in the provision of advice to colleagues. As prior work has suggested (Ickes, Holloway, Stinson, \& Hoodenpyle, 2006), high self-monitors work hard to ensure that social interactions are successful. In the present research this hard work involves being active in helping others with work-related matters. Leadership emergence, therefore, is not just a matter of impression management, as some critics of the self-monitoring and leadership relationship have suggested.

\section{Future Research}

It seems clear that high self-monitors emerge as informal leaders in organizations (Day et al., 2002). But we still do not fully understand the differences between high and low self-monitoring styles of leadership. If we assume that both low and high self-monitors can develop over time as leaders in the eyes of others (as research shows - Tate, 2008), then the interesting question becomes what leadership behaviors differentiate the two self-monitoring orientations. Brokerage across social divides may appeal to the interests and abilities of high self-monitors whereas strengthening connections among members of a team may appeal to the interests and abilities of low self-monitors (Oh \& Kilduff, 2008). Some people may be recognized as leaders because of their institutional loyalty, their retention of the services of trusted subordinates over long periods of time, and their "straight talking." These would seem to be leadership characteristics associated with low selfmonitoring. Other people may be recognized as leaders because of their flexibility in moving from one situation to another, their appeal to different types of people, and their reputation for saying the right thing at the right time. These would seem to be leadership characteristics associated with high self-monitoring. Thus, future research can move beyond the expectation that one type of personality will emerge 
successful in leadership tournaments. Different trajectories and behaviors may be associated with different personality types.

Indeed, high self-monitors' pursuit of informal leadership may be related to costs as well as benefits. Thus, evidence shows that high self-monitors (relative to low self-monitors) are more susceptible to role conflict in the workplace (Mehra \& Schenkel, 2008) and are more likely to accept a range of responsibilities that negatively affect their workplace performance (Mehra et al., 2001). To the extent that the high self-monitors' attitudes and behaviors are driven by external cues (an orientation that may be conducive to getting ahead in organizational contexts), the high self-monitors (relative to the low self-monitors) may be susceptible to influences in the environment such as prompts to eat too much food leading to obesity (Younger \& Pliner, 1976). It is necessary to avoid thinking that one self-monitoring orientation is inevitably superior to the other.

The current research is consistent with other research showing self-monitoring to be associated with leader emergence, but questions remain concerning how individuals different in self-monitoring orientation build bases of trust among colleagues and precisely what kinds of advice high and low self-monitors provide. Previous research has suggested that high and low self-monitors approach relationship building with different orientations. High self-monitors are concerned to project positive images of themselves and to suppress information that might trigger negative inferences (Gangestad \& Snyder, 2000). High self-monitors are also motivated to produce social interactions that are successful (Ickes et al., 2006) and that promote social status (Flynn et al., 2006). By contrast, low self-monitors generate expressive behavior from inner affective states and attitudes (Snyder, 1979) and pay less attention to impression management (Turnley \& Bolino, 2001). Low self-monitors may be strongly motivated to produce social interactions that reflect their genuine underlying values (Ickes et al., 2006). Thus, future research could investigate whether high self-monitors tend to build trusting relationships on the basis of diplomatic impression management, whereas low self-monitors tend to build such relationships on the basis of a match between strongly held values. Further, future research could investigate whether the advice provided by high selfmonitors tends to reflect a status-seeking orientation whereas the advice provided by low self-monitors tends to reflect a sticking-up-for-principles orientation.

Limitations The research is limited in that it draws from cross-sectional data within a single organization. Confidence in the results is enhanced to the extent that they contribute to a consistent pattern that includes laboratory experiments and field studies showing self-monitoring effects on leader emergence (see the review by Day et al., 2002). Given that the culture of the focal organization explicitly valued cooperation, this could limit generalizability of the findings with respect to trust brokerage. Common method bias is always a concern in survey research. We have endeavored to reduce such concern by measuring leadership emergence and advice centrality as counts of nominations by others whereas self-monitoring orientation was based on a well-established self-report instrument. A further limitation of the 
research is that we were not able to explore in depth differences among high and low self-monitors concerning the reasons for the differential pattern of results concerning trust brokerage. An issue for future research is to investigate whether high selfmonitors are better able to exploit brokerage positions in the trust network because they perceive their network positions more accurately (Flynn et al., 2006) or whether network brokers who happen to be high self-monitors have different motivations than their low self-monitoring colleagues.

\section{Conclusion}

Self-monitoring theory shows itself to be valuable in understanding the patterns of leadership emergence in an actual organization in which colleagues provide each other advice and establish patterns of trust and lack of trust. The current research may help to explain why it is that high self-monitors tend to get ahead in the race for promotion and advancement in organizations (Kilduff \& Day, 1994). As individuals pursue their careers, they establish reputations in the eyes of others in terms of leadership behaviors. If self-monitoring theory as employed in this study has an overall message, it is that to understand the structures of social behavior that emerge in organizations we must first understand the psychology of the interacting individuals.

\section{References}

Aiken, L. S., \& West, S. G. (1991). Multiple regression: Testing and interpreting interactions. Thousand Oaks: Sage.

Arvey, R. D., \& Murphy, K. R. (1998). Performance evaluation in work settings. Annual Review of Psychology, 49, 141-168. doi:10.1146/annurev.psych.49.1.141

Bavelas, A. (1950). Communication patterns in task-oriented groups. Journal of the Acoustical Society of America, 22, 725-730. doi:10.1121/1.1906679

Bedeian, A. G., \& Day, D. V. (2004). Can chameleons lead? Leadership Quarterly, 15, 687-718. doi:10.1016/j.leaqua.2004.07.005

Berscheid, E., Graziano, W., Monson, T C., \& Dermer, M. (1976). Outcome dependency: Attention, attribution, and attraction. Journal of Personality and Social Psychology, 34, 978-989. doi:10.1037//0022-3514.34.5.978

Bono, J. E., \& Anderson, M. H. (2005). The advice and influence networks of transformational leaders. Journal of Applied Psychology, 90, 1306-1314. doi:10.1037/0021-9010.90.6.1306

Borgatti, S. P., Everett, M. G., \& Freeman, L. C. (2002). UCINET 6 for Windows: Software for social network analysis. Harvard: Analytic Technologies.

Borgatti, S. P., Jones, C., \& Everett, M. G. (1998). Network measures of social capital. Connections, 21(2), 27-36.

Bretz, R. D. Jr., Milkovich, G. T., \& Read, W. (1992). The current state of performance appraisal research and practice: Concerns, directions, and implications. Journal of Management, 18, 321-352. doi:10.1177/014920639201800206 
Burt, R. S. (1992). Structural holes: The social structure of competition. Cambridge, MA: Harvard University Press.

Burt, R. S. (1997). The contingent value of social capital. Administrative Science Quarterly, 42, 339-365. doi:10.2307/2393923

Burt, R. S. (2005). Brokerage and closure: An introduction to social capital. Oxford: University Press.

Burt, R. S. (2007). Secondhand brokerage: Evidence on the importance of local structure for managers, bankers, and analysts. Academy of Management Journal, 50, 119-148. doi:10.5465/ AMJ.2007.24162082

Burt, R. S., \& Ronchi, D. (1990). Contested control in a large manufacturing plant. In J. Weesie \& H. Flap (Eds.), Social networks through time (pp. 121-157). Utrecht: ISOR.

Carter, L., Haythorn, W., Shriver, B., \& Lanzetta, J. (1951). The behavior of leaders and other group members. Journal of Abnormal and Social Psychology, 46, 589-595. doi:10.1037/ h0059490

Cooper, C. D., Scandura, T. A., \& Schriesheim, C. A. (2005). Looking forward but learning from our past: Potential challenges to developing authentic leadership theory and authentic leaders. Leadership Quarterly, 16, 475-493. doi:10.1016/j.leaqua.2005.03.008

Dabbs, J. M., Evans, M. S., Hopper, C. H., \& Purvis, J. A. (1980). Self-monitors in conversation: What do they monitor? Journal of Personality and Social Psychology, 39, 278-284. doi: 10.1037/0022-3514.39.2.278

Day, D. V., \& Schleicher, D J. (2006). Self-monitoring at work: A motive-based perspective. Journal of Personality, 74, 685-713. doi:10.1111/j.1467-6494.2006.00389.x

Day, D. V., Schleicher, D. J., Unckless, A. L., \& Hiller, N. J. (2002). Self-monitoring personality at work: A meta-analytic investigation of construct validity. Journal of Applied Psychology, 87, 390-401. doi:10.1037//0021-9010.87.2.390

De Cremer, D., Snyder, M., \& Dewitte, S. (2001). The less I trust, the less I contribute (or not)?: The effects of trust, accountability and self-monitoring in social dilemmas. European Journal of Social Psychology, 31, 93-107. doi:10.1002/ejsp.34

Dirks, K. T., \& Ferrin, D. L. (2002). Trust in leadership: Meta-analytic findings and implications for research and practice. Journal of Applied Psychology, 87, 611-628. doi:10.1037/0021-9010.87.4.611

Flynn, F. J., Chatman, J. A., \& Spataro, S. E. (2001). Getting to know you: The influence of personality on impressions and performance of demographically different people in organizations. Administrative Science Quarterly, 46, 414-442. doi:10.2307/3094870

Flynn, F. J., Reagans, R. E., Amanatullah, E. T., \& Ames, D. R. (2006). Helping one's way to the top: Self-monitors achieve status by helping others and knowing who helps whom. Journal of Personality and Social Psychology, 91, 1123-1137. doi:10.1037/0022-3514.91.6.1123

French, J. R. P. Jr., \& Raven, B. (1959). The bases of social power. In D. P. Cartwright (Ed.), Studies in social power (pp. 150-167). Ann Arbor: University of Michigan.

Furnham, A., \& Capon, M. (1983). Social skills and self-monitoring processes. Personality and Individual Differences, 4, 171-178. doi:10.1016/0191-8869(83)90017-X

Gangestad, S. W., \& Snyder, M. (1985). "To carve nature at its joints": On the existence of discrete classes in personality. Psychological Review, 92, 317-349. doi:10.1037/0033-295X.92.3.317

Gangestad, S. W., \& Snyder, M. (2000). Self-monitoring: Appraisal and reappraisal. Psychological Bulletin, 126, 530-555. doi:10.1037//0033-2909.126.4.530

Granovetter, M. S. (1973). The strength of weak ties. American Journal of Sociology, 78, 13601380. doi:10.1086/225469

Hilbe, J. M. (2008). Negative binomial regression. Cambridge, UK: University Press.

Hogan, R., Curphy, G. J., \& Hogan, J. (1994). What we know about leadership: Effectiveness and personality. The American Psychologist, 49, 493-504. doi:10.1037/0003-066X.49.6.493

Homans, G. C. (1951). The human group. London: Routledge \& Kegan Paul. 
Hosch, H. M., Leippe, M. R., Marchioni, P. M., \& Cooper, D. S. (1984). Victimization, self-monitoring, and eyewitness identification. Journal of Applied Psychology, 69, 280-288. doi:10.1037/0021-9010.69.2.280

Huelsenbeck, J. P., Rannala, B. (1997). Phylogenetic methods come of age: Testing hypotheses in an evolutionary context. Science, 276, 227-232. doi:10.1126/science.276.5310.227

Ibarra, H. (1992). Homophily and differential returns: Sex differences in network structure and access in an advertising firm. Administrative Science Quarterly, 37, 422-447. doi:10.2307/ 2393451

Ickes, W., \& Barnes, R. D. (1977). The role of sex and self-monitoring in unstructured dyadic interactions. Journal of Personality and Social Psychology, 35, 315-330. doi:10.1111/ j.1467-6494.2006.00388.x

Ickes, W., Holloway, R., Stinson, L. L., \& Hoodenpyle, T. G. (2006). Self-monitoring in social interaction: The centrality of self-affect. Journal of Personality, 74, 659-684. doi:10:1111/j.1467-6494.2006.00388.x

Ilies, R., Morgeson, F. P., \& Nahrgang, J. D. (2005). Authentic leadership and eudaemonic wellbeing: Understanding leader-follower outcomes. Leadership Quarterly, 16, 373-394.

Jenkins, J. M. (1993). Self-monitoring and turnover: The impact of personality on intent to leave. Journal of Organizational Behavior, 14, 83-91. doi:10.1002/job.4030140108

Jones, E. E., \& Baumeister, R. (1976). The self-monitor looks at the ingratiatory. Journal of Personality and Social Psychology, 44, 654-674. doi:10.1111/j.1467-6494.1976.tb00144.x

Kilduff, M., \& Day, D. V. (1994). Do chameleons get ahead?: The effects of self-monitoring on managerial careers. Academy of Management Journal, 37, 1047-1060. doi:10.2307/256612

Kulik, J. A., \& Taylor, S E. (1981). Self-monitoring and the use of consensus information. Journal of Personality, 49, 75-84. doi:10.1111/j.1467-6494.1981.tb00847.x

Krackhardt, D. (1995). Entrepreneurial opportunities in an entrepreneurial firm: A structural approach. Entrepreneurship Theory and Practice, 19, 53-69.

Lippa, R. (1978). Expressive control, expressive consistency, and the correspondence between expressive behavior and personality. Journal of Personality, 46, 438-461. doi:10.1111/j.1467-6494.1978.tb01011.x

Lord, R. G., De Vader, C. L., \& Alliger, G. M. (1986). A meta-analysis of the relation between personality traits and leadership perceptions: An application of validity generalization procedures. Journal of Applied Psychology, 71, 402-410. doi:10.1037/0021-9010.71.3.402

Lord, R. G., \& Maher, K. J. (1993). Leadership and information processing: Linking perceptions and performance. London: Routledge. (Original work published 1991)

Markovsky, B., Willer, D., \& Patton, T. (1988). Power relations in exchange networks. American Sociological Review, 53, 220-236. doi:10.2307/2095689

Mehra, A., Kilduff, M., \& Brass, D. J. (2001). The social networks of high and low self-monitors: Implications for workplace performance. Administrative Science Quarterly, 46, 121-146. doi: $10.2307 / 2667127$

Mehra, A., \& Schenkel, M. T. (2008). The price chameleons pay: Self-monitoring, boundary spanning and role conflict in the workplace. British Journal of Management, 19, 138-144. doi:10.1111/j.1467-8551.2007.00535.x

Merton, R. K. (1968). Social theory and social structure. New York: Free Press.

Neubert, M. J., \& Taggar, S. (2004). Pathways to informal leadership: The moderating role of gender on the relationship of individual differences and team member network centrality to informal leadership emergence. The Leadership Quarterly, 15, 175-194. doi:10.1016/j. leaqua.2004.02.006

Oh, H., \& Kilduff, M. (2008). The ripple effect of personality on social structure? Self-monitoring origins of network brokerage. Journal of Applied Psychology, 93, 1155-1164. doi:10.1037/0021-9010.93.5.1155

Podolny, J. M., \& Baron, J. N. (1997). Resources and relationships: Social networks and mobility in the workplace. American Sociological Review, 62, 673-693. doi:10.2307/2657354 
Rousseau, D. M., Sitkin, S. B., Burt, R. S., \& Camerer, C. (1998). Not so different after all: A cross-discipline view of trust. Academy of Management Review, 23, 393-404. doi:10.5465/ AMR.1998.926617

Santee, R. T., \& Maslach, C. (1982). To agree or not to agree: Personal dissent amid social pressure to conform. Journal of Personality and Social Psychology, 42, 690-700. doi:10.1037/0022-3514.42.4.690

Seibert, S. E., Kraimer, M. L., \& Liden, R. C. (2001). A social capital theory of career success. The Academy of Management Journal, 44, 219-237. doi:10.2307/3069452

Shaw, M. E. (1964). Communication networks. In L. Nerkowitz (Ed.), Advances in experimental social psychology (pp. 111-147), Vol. 1. New York: Academic Press.

Simmel, G. (1955). Conflict and the web of group-affiliations. New York: Free Press.

Simons, T. (2002). Behavioral integrity: The perceived alignment between managers' words and deeds as a research focus. Organization Science, 13, 18-35. doi:10.1287/orsc.13.1.18.543

Snyder, M. (1979). Self-monitoring processes. In L. Berkowitz (Ed.), Advances in experimental social psychology (pp. 85-128), Vol. 12. New York: Academic Press.

Snyder, M. (1987). Public appearances, private realities: The psychology of self-monitoring. New York: Freeman.

Snyder, M., \& Gangestad, S. (1982). Choosing social situations: Two investigations of self-monitoring processes. Journal of Personality and Social Psychology, 43, 123-135. doi:10.1037/0022-3514.43.1.123

Snyder, M., \& Gangestad, S. (1986). On the nature of self-monitoring: Matters of assessment, matters of validity. Journal of Personality and Social Psychology, 51, 125-139. doi:10.1037/0022-3514.51.1.125

Snyder, M., Gangestad, S., \& Simpson, J. A. (1983). Choosing friends as activity partners: The role of self-monitoring. Journal of Personality and Social Psychology, 45, 1061-1072. doi:10.1037/0022-3514.45.5.1061

Snyder, M., \& Monson, T. C. (1975). Persons, situations, and the control of social behavior. Journal of Personality and Social Psychology, 32, 637-644. doi:10.1037/0022-3514.32.4.637

Sorrentino, R. M., \& Field, N. (1986). Emergent leadership over time: The functional value of positive motivation. Journal of Personality and Social Psychology, 50, 1091-1099. doi:10.1037/0022-3514.50.6.1091

Sparrowe, R. T., \& Liden, R. C. (2005). Two routes to influence: Integrating leader-member exchange and social network perspectives. Administrative Science Quarterly, 50, 505-535. doi:10.2189/asqu.50.4.505

Tate, B. (2008). A longitudinal study of the relationships among self-monitoring, authentic leadership, and perceptions of leadership. Journal of Leadership and Organizational Studies, 15(1), 16-29. doi: $10.1177 / 1548051808318002$

Tetlock, P. E. (1992). The impact of accountability on judgment and choice: Toward a social contingency model. In M. P. Zanna (Ed.), Advances in experimental social psychology (pp. 331376), Vol. 25. San Diego: Academic Press. doi:10.1016/S0065-2601(08)60287-7

Toegel, G., Anand, N., \& Kilduff, M. (2007). Emotion helpers: The role of high positive affectivity and high self-monitoring managers. Personnel Psychology, 60, 337-365. doi:10.1111/j.1744-6570.2007.00076.x

Turner, R. G. (1980). Self-monitoring and humor production. Journal of Personality, 48, 163-167. doi:10.1111/j.1467-6494.1980.tb00825.x

Turnley, W. H., \& Bolino, M. C. (2001). Achieving desired images while avoiding undesired images: Exploring the role of self-monitoring in impression management. Journal of Applied Psychology, 86, 351-360. doi:10.1037/0021-9010.86.2.351

Wherry, R. J. Sr., \& Bartlett, C. J. (1982). The control of bias in ratings: A theory of rating. Personnel Psychology, 35, 521-551. doi:10.1111/j.1744-6570.1982.tb02208.x

Younger, J. C., \& Pliner, P. (1976). Obese-normal differences in the self-monitoring of expressive behavior. Journal of Research in Personality, 10, 112-115. doi:10.1016/0092-6566(76)90089-1 
Zaccaro, S. J., Foti, R. J., \& Kenny, D. A. (1991). Self-monitoring and trait-based variance in leadership: An investigation of leader flexibility across multiple group situations. Journal of Applied Psychology, 76, 308-315. doi:10.1037/0021-9010.76.2.308

Zanna, M. P., Olson, J. M., \& Fazio, R. H. (1980). Attitude-behavior consistency: An individual difference perspective. Journal of Personality and Social Psychology, 38, 432-440. doi:10.1037/0022-3514.38.3.432

Open Access This chapter is distributed under the terms of the Creative Commons Attribution 4.0 International License (http://creativecommons.org/licenses/by/4.0/), which permits use, duplication, adaptation, distribution and reproduction in any medium or format, as long as you give appropriate credit to the original author(s) and the source, provide a link to the Creative Commons license and indicate if changes were made.

The images or other third party material in this chapter are included in the work's Creative Commons license, unless indicated otherwise in the credit line; if such material is not included in the work's Creative Commons license and the respective action is not permitted by statutory regulation, users will need to obtain permission from the license holder to duplicate, adapt or reproduce the material. 